\title{
THE REMNANTS OF MID-FOREST IRON ORE EXCAVATIONS AS A REFUGE FOR LOCAL DIVERSITY IN THE VASCLUAR PLANT FLORA
}

\author{
STRZELECZEK, Ł.* - JĘDRZEJCZYK-KORYCIŃSKA, M. - PIECUCH, I. - ROSTAŃSKI, A. \\ Department of Botany and Nature Protection Faculty of Biology and Environmental Protection \\ University of Silesia, Katowice, Poland \\ *Corresponding author \\ e-mail: l.strzeleczek@gmail.com
}

(Received 24 $4^{\text {th }}$ Mar 2017; accepted $1^{\text {st }}$ Aug 2017)

\begin{abstract}
Former excavation remnants can play a significant role in increasing the species richness and local biodiversity on heavily altered, post-industrial sites. In this article we examined 30 plots mounds and areas surrounding mounds to evaluate the influence of different key factors on floristic composition, including selected edaphic parameters $\left(\mathrm{pH}, \mathrm{EC}\right.$, organic matter, $\mathrm{CaCO}_{3}$ and content of metals: $\mathrm{Pb}, \mathrm{Cd}, \mathrm{Zn}, \mathrm{Fe}$ ). We also tested the species-area correlations. Additionally, we assessed basic characteristics of plant species, which inhabit those plots, measuring species richness and biodiversity with Shannon-Weiner index $\left(\mathrm{H}^{\prime}\right)$ and also estimating the similarities in species composition between mounds and the surrounding areas, using Sörensen's index $\left(\mathrm{S}_{\mathrm{o}}\right)$. In result, we noted 92 vascular plant species, with mostly native origin (98\%). Based on the performed analysis, mounds which were studied had slightly higher values of mean species richness and species diversity compared to the surrounding area. Contribution of socio-ecological groups showed, that, mounds were inhabited predominantly by forest species from Querco-Fagetea and Vaccinio-Piceetea classes. Analyses of collected soil samples indicated strong influence of $\mathrm{pH}$ and content of metals (mostly zinc, lead and iron) in relation to the floristic composition on the examined plots. Unique characteristics of soil samples taken from the studied plots can explain the distinct preferences of some plant species which grow on them. This allowed to classify those structures as a refuge area, considering their positive contribution to the increase of species richness and biodiversity. Nowadays the old remnants can be also treated as a crucial part of historical and cultural heritage.
\end{abstract}

Keywords: habitat islands, species richness, human disturbance, local biodiversity, abiotic characteristics

\section{Introduction}

A variety of landscape modifications, which relate to anthropological use and particularly, human destruction of natural habitats, can influence and increase the process of habitat fragmentation, directly threatening the natural state of balance in local diversity (Andrén, 1997). Despite that,, many forms of remnants such as excavations, pits or tailings positively influence species composition during the long term process of reclamation, which occur on them. Man-made sites can also become local shelters for many endangered plant species (Rehounková and Prach, 2006; Rostański, 2005, 2006; Bzdon, 2008; Czylok and Szymczyk, 2009). Due to their distinctive characteristics and role in the process of landscape fragmentation, these structures can be treated as small habitat islands, which corresponds with the main concept of biogeographical theory proposed by MacArthur and Wilson (1967). The state of equilibrium, according to this theory, can be achieved, depending on few basic factors, such as the immigration and extinction rate of plant species, size of studied "island" and level of its isolation from similar structures. In the case of remnants of past activities, we have to consider 
numerous amount of human-based disturbances in form of mining and excavating among the crucial factors, which characterize those differences. In this article we attempt to make a detailed studies on the remnants of mid forest iron ore excavations as a refuge area for local diversity of vascular plant flora, emphasizing the influence of heavily modified abiotic and biotic parameters. We would also like to verify whether other factors (such as the size of the mounds studied) can affect the state of local biodiversity, in accordance with the biogeographical theory of habitat islands.

\section{Materials and methods}

\section{Study area}

The fieldwork area is located in the Forest District of Koszęcin (Boronów Forestry Katowice directorate: 118g, 118c, 118a, 117h, 117i, 117g, 117d, 98c and 98i). Fifteen mounds (remnants of iron ore excavation) were investigated during this project. Records were made of vascular plant species composition on those structures, as well as on their surrounding area (Fig. 1), located in the vicinity of two settlements Boronów and Zumpy (Silesian voivodeship). Most of them were already buried and covered by surface layer of soil. Some of the shafts investigated were flooded and then transformed into small artificial reservoirs of rainwater (Fig. 2). Every mound was thoroughly measured and their basic parameters were taken, including: length, width, area, height (max and min), the diameter of internal shafts, located on top of the mounds, type of forest habitat and also the GPS coordinates (Tab. 1)

Table 1. Characteristics of the mounds (based on own data)

\begin{tabular}{|c|c|c|c|c|c|c|c|c|c|}
\hline$\dot{z}$ & 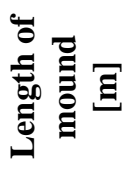 & 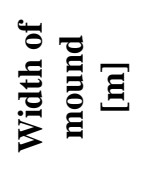 & 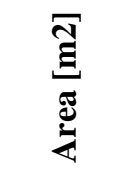 & 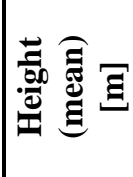 & 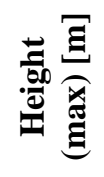 & 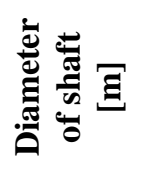 & 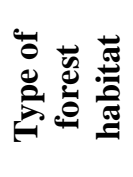 & 芯 & 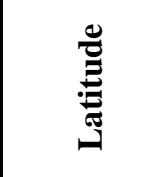 \\
\hline 1 & 35 & 25 & 875 & 2.5 & 3 & 1.6 & MFF & 50.69694 & 18.8998 \\
\hline 2 & 25 & 24 & 600 & 2.2 & 2.9 & 2 & $\mathrm{FCF}$ & 50.69682 & 18.90066 \\
\hline 3 & 26 & 25 & 650 & 3.5 & 4 & 6 & MFF & 50.69738 & 18.89981 \\
\hline 4 & 30 & 25.5 & 765 & 3 & 3.3 & 5 & $\mathrm{FCF}$ & 50.69737 & 18.90073 \\
\hline 5 & 35.5 & 17.5 & 621.25 & 3.5 & 3.8 & 1.2 & MFF & 50.69807 & 18.89973 \\
\hline 6 & 26 & 23 & 598 & 5.5 & 8.5 & 5 & $\mathrm{FCF}$ & 50.69837 & 18.89893 \\
\hline 7 & 34 & 28 & 952 & 2.8 & 3 & 1.8 & $\mathrm{FCF}$ & 50.69787 & 18.90064 \\
\hline 8 & 26 & 26 & 676 & 3 & 3 & 2 & $\mathrm{FCF}$ & 50.69854 & 18.90053 \\
\hline 9 & 34.5 & 31 & 1069.5 & 3.5 & 3.7 & 2 & $\mathrm{FCF}$ & 50.69858 & 18.89992 \\
\hline 10 & 28 & 27 & 756 & 2 & 3 & 3 & MFF & 50.69595 & 18.90024 \\
\hline 11 & 30 & 25 & 750 & 2 & 2 & 2 & $\mathrm{MCF}$ & 50.69909 & 18.90058 \\
\hline 12 & 27 & 24 & 648 & 2 & 4 & 5 & MCF & 50.69959 & 18.90064 \\
\hline 13 & 24.5 & 21 & 514.5 & 1.8 & 4 & 1.5 & MCF & 50.69909 & 18.89985 \\
\hline 14 & 24.5 & 19 & 465.5 & 3 & 4.5 & 4 & MCF & 50.69915 & 18.89893 \\
\hline 15 & 28.5 & 24.5 & 698.25 & 5.5 & 6 & 5 & WCF & 50.69967 & 18.89976 \\
\hline
\end{tabular}

MFF - mixed fresh forest, $\mathbf{M C F}$ - mixed coniferous forest, $\mathbf{W C F}$ - wet coniferous forest 


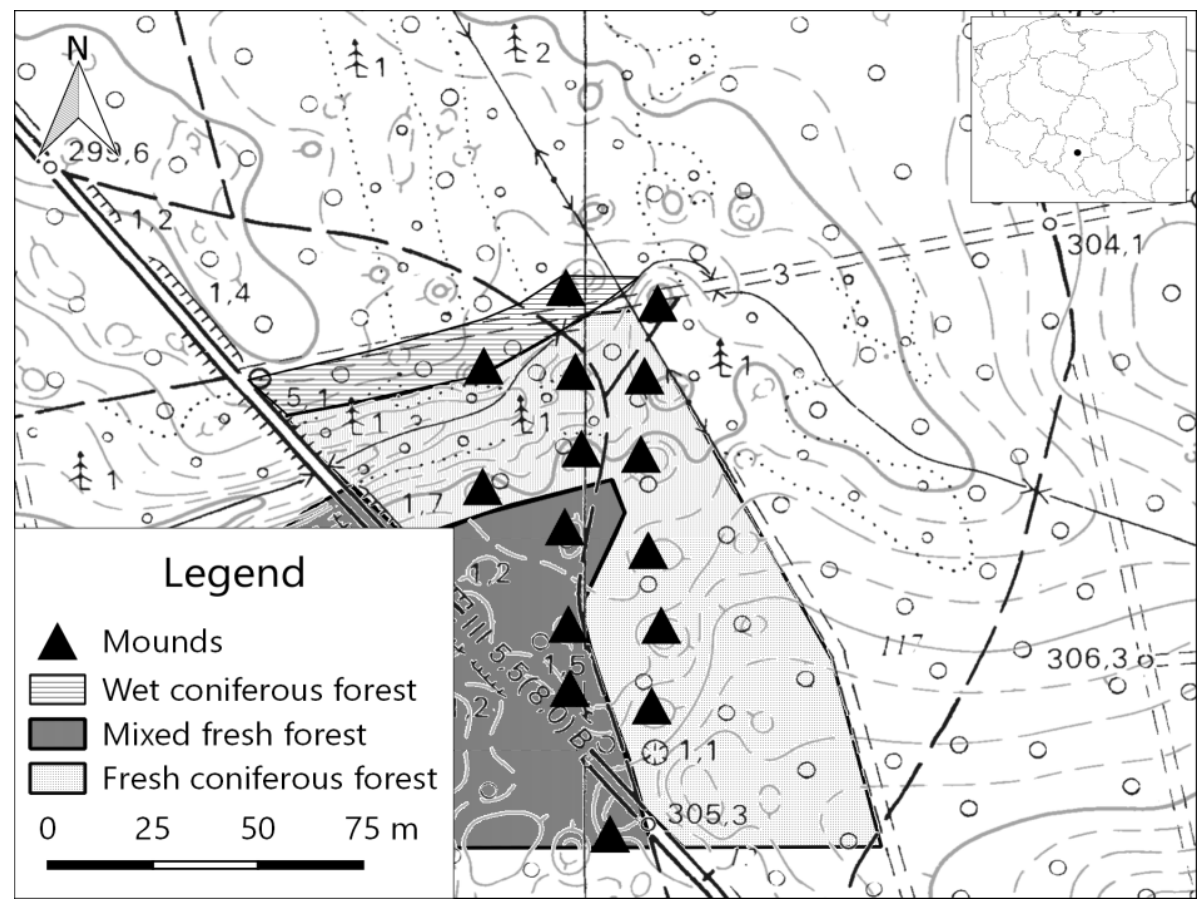

Figure 1. Localities of excavation remnants - mounds (source: http://www.geoportal.gov.pl, modified)

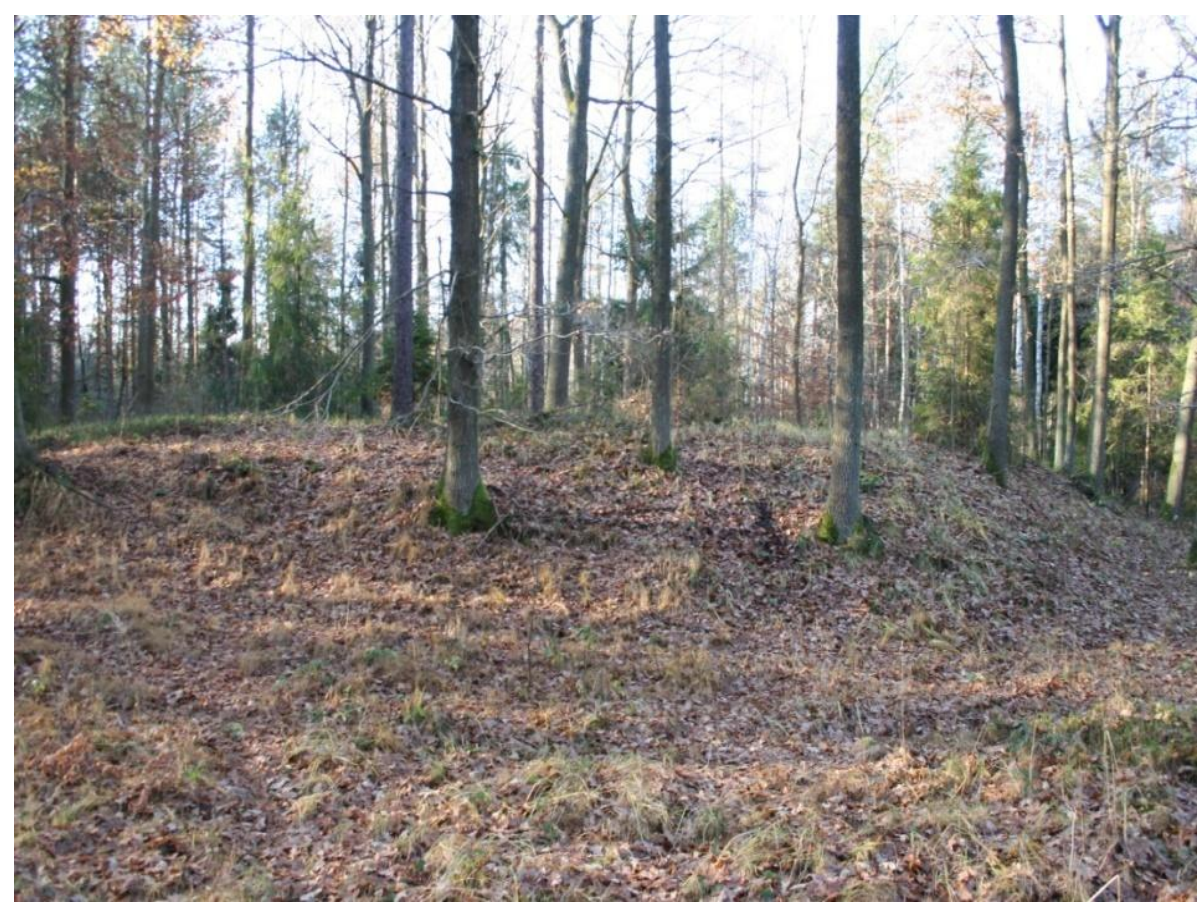

Figure 2. Sample picture illustrating mound and surrounding area (photo A. Rostański)

\section{Climate and geological conditions}

The area of our studies corresponds with the climatic region of western part of the Lesser Poland voivodship, according to the division proposed by Woś (1999). This 
region is characterized by considerably high amount of annual rainwater, due to its specific features, which are typical on the upland site. The mean values of annual temperature set at around $7-8^{\circ} \mathrm{C}$ (the peak is around $14^{\circ} \mathrm{C}$ in July and the lowest value is $-4^{\circ} \mathrm{C}$ in January). The monthly mean values of rainfall water hover at around 80 $\mathrm{mm} / \mathrm{m}^{2}$ in July and drop to the $40 \mathrm{~mm} / \mathrm{m}^{2}$ in the following months (Fig. 3). The winds are mainly western with relatively low speed.

Land relief has slightly sinuous profile with small elevations reaching up to the several meters above ground. In terms of soil conditions, there are mainly 2 types of soils distinguished in this area: proper fallow soils (mostly occurring in the directorates 117 and $118 \mathrm{~g}$ ) and the proper pseudogley soils (occurring in the directorates $118 \mathrm{c}$, a and 98 c) (Operat siedliskowy, 2003).

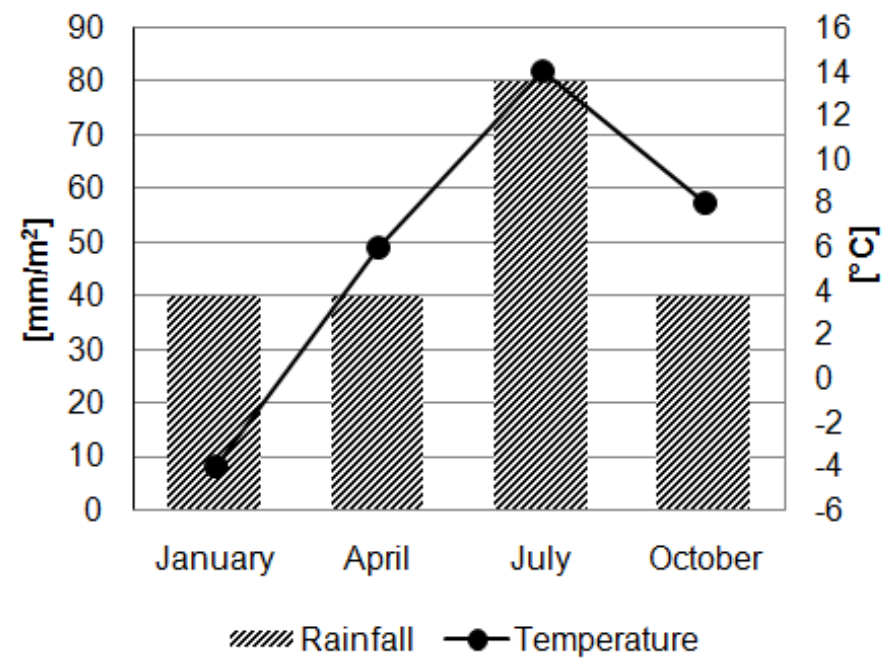

Figure 3. Climate diagram of area studied with the temperature and rainfall mean values in selected months (source: Kruczała, 2000, modified)

\section{Methods of fieldwork sampling}

For the investigation we established 30 assessment plots, which were differentiated into the excavation mounds themselves (M) and the strip of land around each mound (15 metre in diameter), which was referred to as the surrounding area $(\mathrm{S})$. We used the standard Braun-Blanquet method (1928) to assess cover and constancy for each individual species in the relevés with modified scale (Tab. 2). Within those plots, 30 soil samples from depth of 10-15 cm (root zone) were taken (bulk samples from each mound and surrounding area) and prepared for the laboratory analysis.

Table 2. Constancy scale for species noted

\begin{tabular}{c|c}
\hline Degree & \% constancy \\
\hline V & $100-80$ \\
IV & $80-60,1$ \\
III & $60-40,1$ \\
II & $40-20,1$ \\
I & $20-1$ \\
\hline
\end{tabular}




\section{Methods of biotic analyses}

The nomenclature for plant species was taken from Mirek et al. (2002). Their origin (including apophytes - native species occurring on synanthropic habitats and kenophytes - species permanently established in Poland after the year of 1500) was based on classifications from Tokarska-Guzik (2005) and Mirek et al. (2002). Affinity to socio-ecological groups of designated plant communities was assigned, based on classification of Matuszkiewicz (2007) with distinction of 6 classes, which had the highest contribution: Querco-Fagetea and Vaccinio-Piceetea (forest communities), Molinio-Arrhenatheretea and Epilobietea angustifolii (wet meadows and nitrophilous communities), Nardo-Callunetea (turfs and moors communities) and Artemisietea vulgaris (ruderal communities of perennials). Relevant species traits, including life strategies were estimated, based on Grime $(1979,2002)$ and Klotz et al. (2002) classifications, which allowed primary strategies $(\mathrm{C}$ - competitors, $\mathrm{R}$ - ruderals, $\mathrm{S}$ stress tolerators) to be distinguished, as well as some of the mixed strategies (CR composition/ruderal, CS - competitors/stress tolerators, SR - stress tolerators/ruderals and CSR - competitors/stress tolerators/ruderals).

\section{Vegetation diversity and similarity indices}

The level of overall biodiversity within plots was measured using the ShannonWiener index of diversity ( $\mathrm{H}^{\prime}$ ), based on the species cover values noted (Whittaker 1972), according to this formula:

$$
\mathrm{H}^{\prime}=-\sum_{\mathrm{i}=1}^{\mathrm{n}} P i \ln P i
$$

$\boldsymbol{P i}$ - number of individuals of i-th species

$\boldsymbol{n}$ - total number of species

In order to measure the similarity level in species composition between mounds and surrounding area plots, Sörensen index of similarity $\left(\mathrm{S}_{\mathrm{o}}\right)$ was applied (Trojan, 1980), as the necessary calculations were made according to this formula:

$$
\mathrm{So}=\frac{2 \mathrm{c}}{\mathrm{a}+\mathrm{b}} \times 100 \%
$$

where a represents the number of species on the mounds, $\mathbf{b}$ represents the number of species in the surrounding area and $\mathbf{c}$ represents the number of species which are common for both facilities. This index shows the resemblance on the percentage scale, where $0 \%$ means lack of any common species between specific mound and its surrounding area and $100 \%$ means that, species composition in both cases is identical.

\section{Methods of soil sample analysis}

The soil samples collected from the plots were dried at $105{ }^{\circ} \mathrm{C}$ and sieved through $2 \mathrm{~mm}$ mesh. Active $\mathrm{pH}\left(\right.$ in $\mathrm{H}_{2} \mathrm{O}$ ) and electric conductivity (EC) were measured using a $\mathrm{pH} /$ conductivity/TDS meter. The content of organic matter $(\% \mathrm{OM})$, was measured, based on the loss of ignition analysis of dried samples. Percentage equivalent of the calcium carbonate $\left(\% \mathrm{EqCaCO}_{3}\right)$, was estimated using Scheibler's method. Metal 
concentrations (lead, cadmium, zinc and iron) in the soil samples were analyzed using the flame atomic absorption spectrometry (AAS).

\section{Statistical methods and correlations}

All of the listed parameters, which refer to the vegetation (diversity index and number of species noted) and soil ( $\mathrm{pH}$, electric conductivity, $\% \mathrm{EqCaCO}_{3}$, content of organic matter, content of metals) properties have been also measured, to identify statistical differences in pairs of plots (mound-surrounding area) using standard UMann Whitney test. For the correlation in species diversity-area model we transformed data using semi-log scale and used linear regression method and also testing the statistical significance. We applied the canonical correspondence analysis (CCA) to estimate the species-environmental relations and we also used the cluster analysis (Ward method with Euclidean distance) to indicate whether the physico-chemical variables are distinctive for each group of plots. The following software was used to perform the statistical calculations and visual interpratations: CANOCO 4.5 (Ter Braak and Šmilauer, 2002; Lepš and Šmilauer, 2003) Statistica 12 (StatSoft 2011) and RStudio 1.01 (2015).

\section{Results}

\section{Vegetation diversity and similarity measurements}

There were 92 vascular plant species noted together on the mounds and their surrounding area (Appendix 1). Based on the mean values of the species diversity indices we observed that, the mounds had slightly higher species richness compared with the area which surrounded them $(23 \pm 2.21$ on mounds and $19 \pm 2,13$ in the surrounding area), following the slightly higher values of species biodiversity noted ( $4.31 \pm 0.15$ on mounds and $4.01 \pm 0,15$ in the surrounding area), although that, difference between those groups was estimated as not statistically significant according to the results of conducted U-Mann Whitney test (Tab. 3).

Table 3. Mean values (with standard error) for biotic parameters and results of the U-Mann Whitney test $(*$ - significance at $p<0.001)$

\begin{tabular}{c|c|c|c|c}
\hline Parameters & Mounds & Sur. area & $\mathbf{Z}$ & $\mathbf{p}$ \\
\hline Number of species & $23 \pm 2.21$ & $19 \pm 2,13$ & 1.267339 & 0.205035 \\
Diversity index $\left(\mathbf{H}^{\prime}\right)$ & $4.31 \pm 0.15$ & $4.01 \pm 0,15$ & 1.244342 & 0.213375 \\
\hline
\end{tabular}

Native species (98\%) were almost exclusively building the composition of the flora investigated, which is a commonly observed phenomenon on abandoned areas with post industrial origin. Only $2 \%$ of the total composition was represented by alien species (kenophytes), such as: Impatiens parviflora (mainly concentrated in the surrounding area) and Quercus rubra, (recorded on one of the studied mounds).

There were 13 different socio-ecological classes distinguished in the plots sampled, although some of them were represented only by single species. Most of the mid-forest mounds consisted of typical forest and scrub species (representing the classes: QuercoFagetea and Vaccinio-Piceetea). Together they exceeded a contribution of 38\%. The second and also influential group, consisted of fresh meadows species (representing the 
class: Molinio-Arrhenatheretea) (Fig. 4), with a contribution level of $18 \%$. If the results are compared the in three different groups of species, representing those which occurred only on mounds $(\mathrm{M})$, those which occurred on mounds and in the surrounding area $(\mathrm{M} / \mathrm{S})$ and those which occurred only in the surrounding area $(\mathrm{S})$, we observed a higher contribution of species from Querco-Fagetea and Artemisietea vulgaris classes, which were present only on mounds, compared with those species, which exclusively inhabit the surrounding area (Fig. 5).

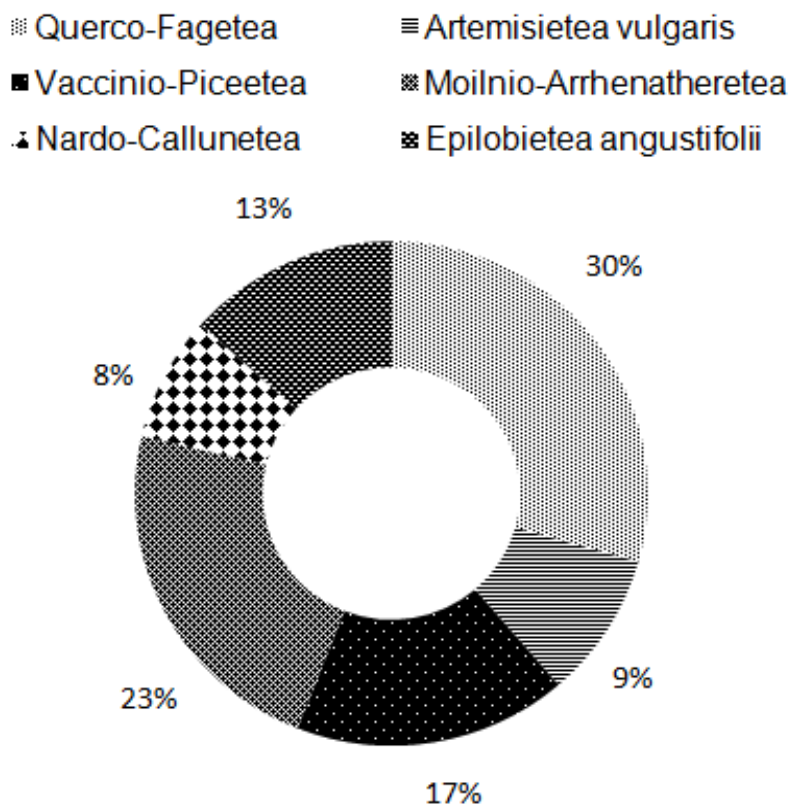

Figure 4. Contribution of the most numerous socio-ecological classes (based on total flora)

× Trifolio-Geranitea Sanguinei
$\approx$ Rhamno-Prunetea
$\approx$ Quercetea robori-petraeae
$\approx$ Epilobietea angustifolii
N Nardo-Callunetea
- Moilnio-Arrhenatheretea
$\equiv$ Artemisietea vulgaris
$\because$ Querco-Fagetea

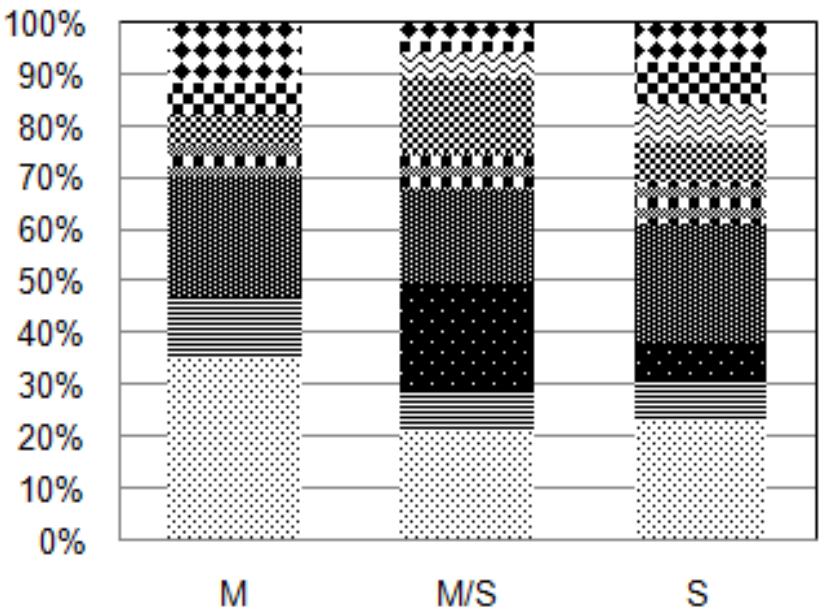

Figure 5. Contribution of socio-ecological classes based on the species occurrence (only on mounds $-M$, on mounds and surrounding area $-M / S$, only in the surrounding area $-S$ )

These mid-forest excavating mounds and the areas immediately around them were predominantly inhabited by species which represented C (competitors) strategy (33) and 
CSR (competitors/stress tolerators/ruderals) strategy (30) (Fig. 6). The contribution of species, representing $\mathrm{C}$ and CS strategies was higher on mounds, although surrounding areas had slightly higher contribution of species with CSR type of life strategy.

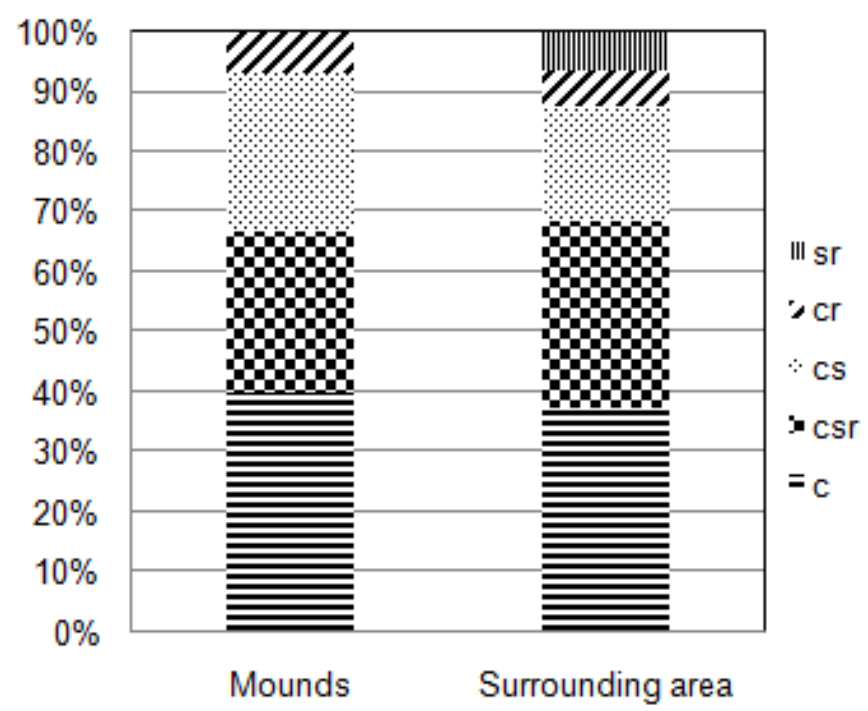

Figure 6. Contribution of life strategies in both groups of plots

Most of the species noted belong to constancy class I both on the mounds (12) and in the surrounding area (14), which corresponds with a low amount of individual species and a relatively high contribution of common ones, although a few species were present only on mounds and had substantially high level of constancy there (IV, III and II classes of constancy). In addition, some plant species were present only in the areas around the mounds (II and III classes of constancy) (Fig. 7 and Tab. 4). Rare and valuable plant species, like: Daphne mezereum (IV class), Luzula multiflora (II class), Galium schultesii (II class) represented the general group, whose occurrence was exclusively limited to the mounds. At the opposite extreme, common woody species, such as: Acer platanoides (II class) and Hieracium murorum (III class) had relatively high frequency level in the surrounding area.

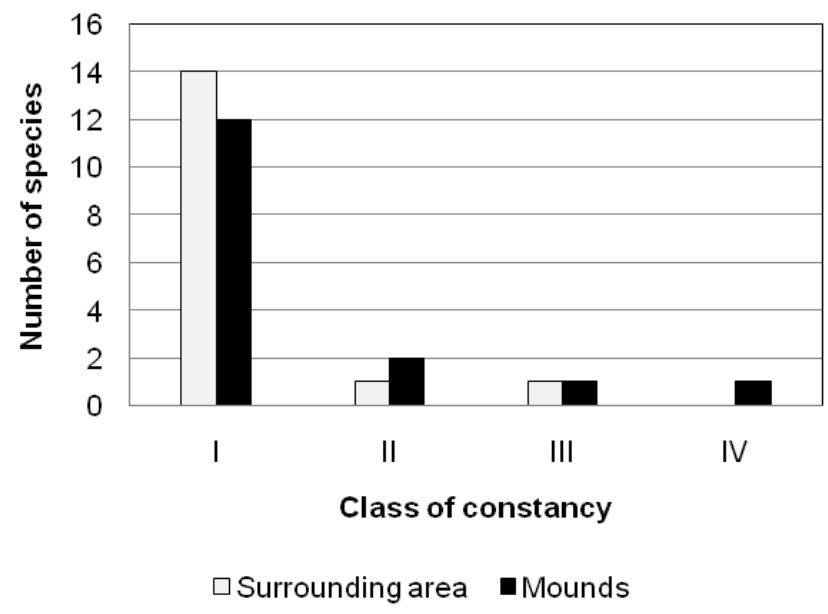

Figure 7. Number of species in the distinguished classes of constancy 
Table 4. Constancy values for the plant species which exclusively appear on mounds or in the surrounding area

\begin{tabular}{|c|c|c|c|c|c|}
\hline & Species name & $\mathbf{I}$ & II & III & IV \\
\hline \multirow{16}{*}{$\begin{array}{l}\frac{\mathscr{0}}{0} \\
\frac{0}{0} \\
\frac{0}{0} \\
\frac{5}{3} \\
\frac{0}{\Sigma}\end{array}$} & Astragalus glycyphyllos & $\bullet$ & & \multirow{16}{*}{ • } & \multirow{32}{*}{$\bullet$} \\
\hline & Carex spicata & - & & & \\
\hline & Corylus avellana & • & \multirow{12}{*}{$\bullet$} & & \\
\hline & Epilobium roseum & - & & & \\
\hline & Galium aparine & - & & & \\
\hline & Lychnis flos-cuculi & • & & & \\
\hline & Melica nutans & - & & & \\
\hline & Prunus spinosa & - & & & \\
\hline & Senecio ovatus & - & & & \\
\hline & Stachys sylvatica & • & & & \\
\hline & Scutellaria galericulata & • & & & \\
\hline & Vicia sylvatica & - & & & \\
\hline & Galium schultesii & & & & \\
\hline & Luzula multiflora & & & & \\
\hline & Lathyrus pratensis & & & & \\
\hline & Daphne mezereum & & & & \\
\hline \multirow{16}{*}{ 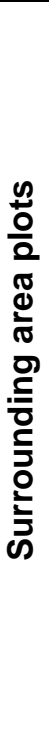 } & Agrostis capilaris & $\bullet$ & \multirow{16}{*}{ • } & \multirow[b]{16}{*}{ - } & \\
\hline & Calluna vulgaris & • & & & \\
\hline & Circaea lutetiana & - & & & \\
\hline & Centaurium erythreaea & - & & & \\
\hline & Epilobium hirsutum & • & & & \\
\hline & Festuca gigantea & • & & & \\
\hline & Jasione montana & - & & & \\
\hline & Phleum pratense & • & & & \\
\hline & Polygonum persicaria & • & & & \\
\hline & Potentilla anserina & - & & & \\
\hline & Sarothamnus scoparius & • & & & \\
\hline & Prunella vulgaris & - & & & \\
\hline & Quercus rubra & • & & & \\
\hline & Mentha arvensis & \multirow{3}{*}{ • } & & & \\
\hline & Acer platanoides & & & & \\
\hline & Hieracium murorum & & & & \\
\hline
\end{tabular}

The comparison between mounds and their surrounding areas in regard to their level of similarity highlighted some noticeable discrepancy between studied groups of plots. The highest values of Sörensen coefficient were noted on mounds $14\left(\mathrm{~S}_{\mathrm{o}}=61.54 \%\right)$ and $15\left(\mathrm{~S}_{\mathrm{O}}=60 \%\right)$ with 8 and 6 common species. In the contrary, one of the lowest levels of similarity were noted in the plots $9\left(\mathrm{~S}_{\mathrm{o}}=38.89 \%\right)$ and $13\left(\mathrm{~S}_{\mathrm{o}}=41.38 \%\right)$ with 7 and 6 common species respectively (Fig. 8 and Tab. 5). Furthermore, one of the biggest mounds (with number 9 and 13) had the lowest value of commonly shared species which indicates their substantial distinctiveness compared to the smaller ones. This also proves the theory, that, those habitats which correspond with the large islands are less prone to the extinction threat with their optimized species pool. 


\section{The relationship between species diversity and area of mounds}

We also wanted to examine the linear correlation in the commonly used species-area model, although we put more focus on the investigation of species diversity of local plant communities, which better emphasizes the essentials of our studies. In case of our mounds which have been divided into three separate size categories (Tab. 6), the correlation between those variables was determined as positive, although not statistically significant $\left(r^{2}=0.2923, P=0.021\right)$. According to the previously mentioned theory, relatively small mounds, due to the size limitations, tend to have less diverse species pool, comparing to the bigger ones which, but at the same time, can support more heterogeneous habitats. Moreover, the biggest mound reached its threshold which resulted in much lower species diversity compared to the other structures (Fig. 9).

Table 5. Number of species (mean \pm SE) which are present on the plots (commonly, only on the mounds, only in the surrounding area)

\begin{tabular}{c|c|c|c}
\hline \multirow{2}{*}{$\begin{array}{c}\text { Number of } \\
\text { mound }\end{array}$} & \multicolumn{2}{|c|}{ Number of species present } & $\begin{array}{c}\text { Number of } \\
\text { common } \\
\text { species }\end{array}$ \\
\cline { 2 - 3 } & Mound & Surrounding area & 19 \\
$\mathbf{1}$ & 35 & 36 & 17 \\
$\mathbf{3}$ & 27 & 32 & 10 \\
$\mathbf{4}$ & 27 & 17 & 13 \\
$\mathbf{5}$ & 34 & 23 & 8 \\
$\mathbf{6}$ & 18 & 19 & 6 \\
$\mathbf{7}$ & 12 & 13 & 16 \\
$\mathbf{8}$ & 40 & 31 & 13 \\
$\mathbf{9}$ & 27 & 23 & 7 \\
$\mathbf{1 0}$ & 21 & 15 & 6 \\
$\mathbf{1 1}$ & 15 & 10 & 8 \\
$\mathbf{1 2}$ & 22 & 11 & 8 \\
$\mathbf{1 3}$ & 20 & 17 & 6 \\
$\mathbf{1 4}$ & 17 & 12 & 6 \\
$\mathbf{1 5}$ & 11 & 9 & 8 \\
\hline Mean \pm SE & $\mathbf{2 3} \pm \mathbf{2 . 2 1}$ & 13 & $\mathbf{1 0} \pm \mathbf{1 . 1 0}$ \\
\hline
\end{tabular}

Table 6. Species diversity in relation to the different size categories distinguished $\left(H^{\prime}-\right.$ diversity index)

\begin{tabular}{|c|c|c|}
\hline Categories & Area $\left[\mathrm{m}^{2}\right]$ & $\mathbf{H}^{\prime}$ \\
\hline \multirow{3}{*}{ Small mounds $\left(<600 \mathrm{~m}^{2}\right)$} & 465.5 & 3.316 \\
\hline & 514.5 & 4.024 \\
\hline & 598 & 3.472 \\
\hline \multirow{5}{*}{ Medium mounds $\left(600-800 \mathrm{~m}^{2}\right)$} & 600 & 4.687 \\
\hline & 621.25 & 4.059 \\
\hline & 648 & 4.262 \\
\hline & 650 & 4.658 \\
\hline & 676 & 4.677 \\
\hline
\end{tabular}




\begin{tabular}{c|c|c}
\hline & 698.25 & 3.683 \\
& 750 & 4.359 \\
& 756 & 3.865 \\
Large mounds $\left(>\mathbf{8 0 0} \mathbf{~ m}^{\mathbf{2}}\right)$ & 765 & 4.999 \\
\hline & 875 & 5.058 \\
& 952 & 5.266 \\
& 1069.5 & 4.303 \\
\hline
\end{tabular}

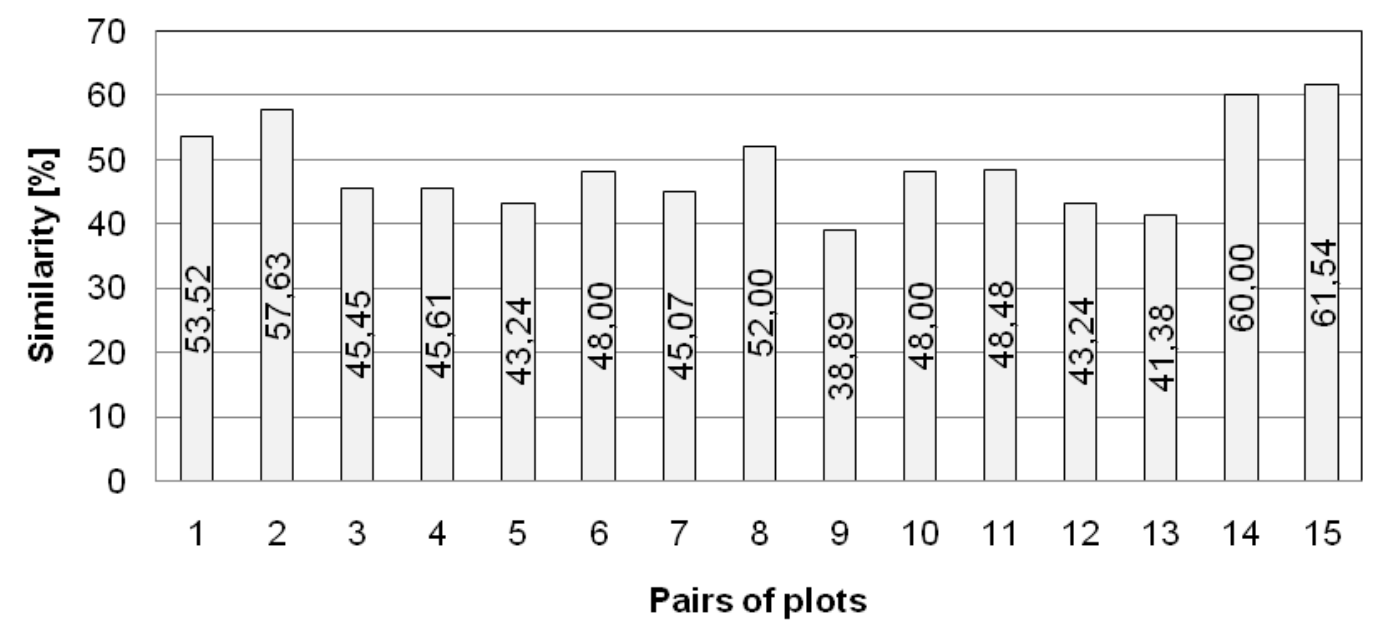

Figure 8. Sörensen's index of species similarity for pairs of plots (mound-surrounding area)

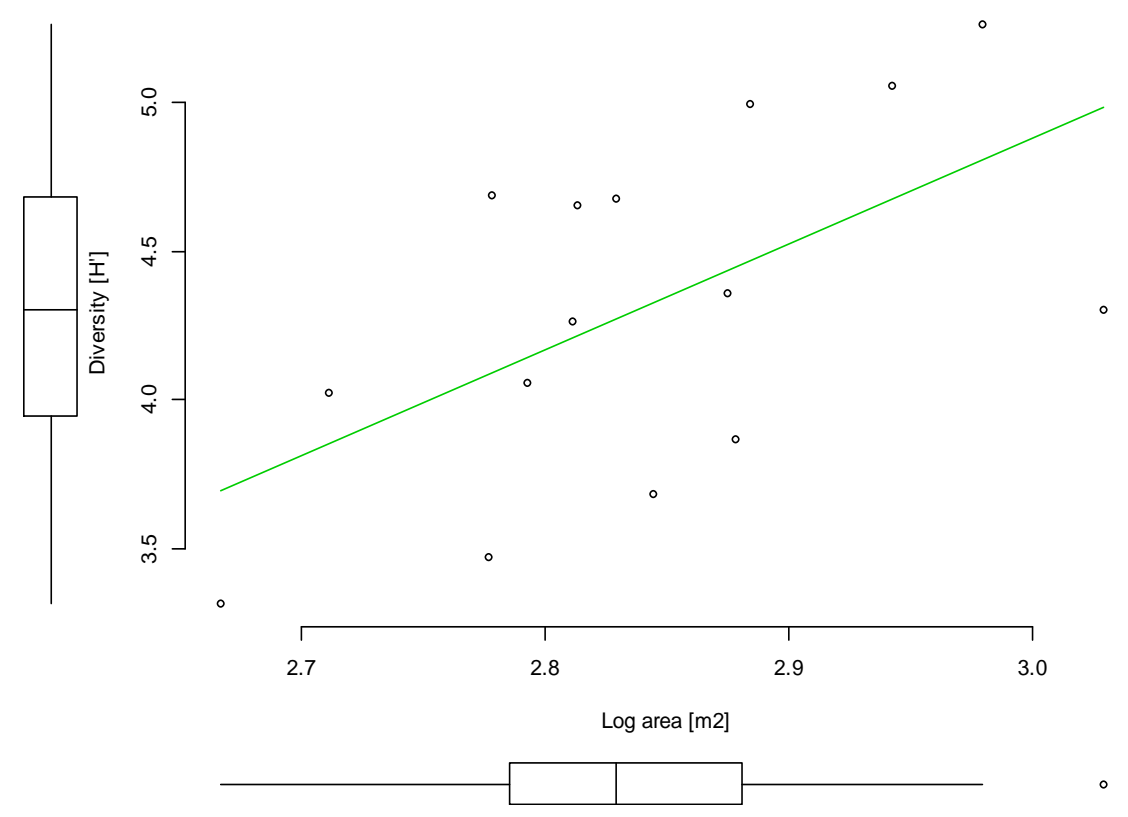

Figure 9. The relationship between species diversity $\left(H^{\prime}\right)$ and size of the mounds $(n=15, y=3.6 x-5.8)$ 


\section{Correlation between soil parameters and composition of vascular plant flora}

We determined that, there is a difference between soil samples taken from mounds and surrounding areas, specifically related to the variables: $\mathrm{pH}(Z=4.21 ; \mathrm{p}=0.000025)$, content of zinc $(\mathrm{Zn})(\mathrm{Z}=4.64 ; \mathrm{p}=0000003)$ and iron $(\mathrm{Fe})(\mathrm{Z}=4.64 ; \mathrm{p}=0000003)$ with the significance level confirmed by the results of the U-Mann Whitney test (Tab. 7). The values of these variables also indicate the main components in the canonical correspondence analysis. The respective scores of canonical correspondence analysis showed, that, the first and second axis describe $13.1 \%$ of total variation in the floristic composition ( $\mathrm{Tab}$. 8). One of the analyzed edaphic factors (content of calcium carbonate $\left.\left(\mathrm{Eq} \% \mathrm{CaCO}_{3}\right)\right)$ was omitted due to its ambiguous correlation to both axes, which caused slight distortion. The right side of the graph (Fig. 10) presents a group of correlated variables $(\mathrm{pH}, \mathrm{Fe}$ and $\mathrm{Zn})$, which corresponds with the first axis positively and also explains the external differentiation between mounds $(\mathrm{M})$ and surrounding area $(\mathrm{S})$. The second, quite substantial group (related to organic matter, electric conductivity and content of $\mathrm{Cd}$ and $\mathrm{Pb}$ ) is correlated with the second axis, which is more likely responsible for the process of internal differentiation within each group of plots (mounds and surrounding areas respectively).

The cluster analysis (Ward method with the Euclidean distance) also highlighted the fact, that, the environmental conditions of studied sites (mounds and surrounding areas) are definitely unique, which manifested in occurance of two major groups of variables and one additional group on the graph (Fig. 11). The first group (on the right side) of surrounding area plots $(\mathrm{S})$ is considered less homogenous with two subgroups representing greater distance between them. In contrary, in the second group (in the middle) there was only single plot (13) separating from the main two subgroups, although the distance between those two major subgroups is considerably smaller. The appearcence of mixed group (with surrounding area and mound plots) explains the fact, that, some of the plots were located in the same linear transect.

Table 7. Mean values (with standard error) for the soil parameters (*_significance measured by the U-Mann Whitney test at $p<0.001$ )

\begin{tabular}{|c|c|c|c|c|}
\hline Parameters & Mounds & Sur. area & $\mathbf{Z}$ & $\mathbf{p}$ \\
\hline $\mathrm{pH}_{\mathrm{H} 2 \mathrm{O}}$ & $4.94 \pm 0.11$ & $4.09 \pm 0.09$ & 4.210492 & $0.000025^{*}$ \\
\hline $\mathrm{EC}[\mu \mathrm{S}]$ & $106.06 \pm 12.43$ & $86.13 \pm 9.16$ & 0.871524 & 0.383469 \\
\hline OM [\%] & $16.66 \pm 1.43$ & $13.06 \pm 1.91$ & 1.907991 & 0.056393 \\
\hline $\mathrm{Pb}\left[\mathrm{mg} \mathrm{kg}^{-1}\right]$ & $68.55 \pm 11.37$ & $62.94 \pm 9.79$ & 2.115381 & 0.034398 \\
\hline $\mathrm{EqCaCO}_{3}[\%]$ & $0.15 \pm 0.04$ & $0.08 \pm 0.02$ & 0.943011 & 0.345676 \\
\hline $\mathrm{Cd}\left[\mathrm{mg} \mathrm{kg}^{-1}\right]$ & $1.37 \pm 0.29$ & $0.58 \pm 0.13$ & 0.248868 & 0.803463 \\
\hline $\mathrm{Zn}\left[\mathrm{mg} \mathrm{kg}^{-1}\right]$ & $167.2 \pm 12.88$ & $39.05 \pm 5.91$ & 4.645544 & $0.0000003 *$ \\
\hline $\mathrm{Fe}\left[\mathrm{mg} \mathrm{kg} \mathbf{~ k}^{-1}\right]$ & $52104.03 \pm 5513.39$ & $6310.02 \pm 1314.98$ & 4.645544 & $0.0000003 *$ \\
\hline
\end{tabular}


Table 8. Summary results of CCA analysis of plots studied

\begin{tabular}{c|c|c|c|c}
\hline Axes: & $\mathbf{1}$ & $\mathbf{2}$ & $\mathbf{3}$ & $\mathbf{4}$ \\
\hline Eigenvalues: & 0.305 & 0.116 & 0.103 & 0.086 \\
Species-environment correlations: & 0.916 & 0.817 & 0.784 & 0.758 \\
Cumulative percentage variance of species data: & 9.5 & 13.1 & 16.3 & 18.9 \\
of species-environment relation: & 39.3 & 54.3 & 67.5 & 78.6 \\
\hline
\end{tabular}

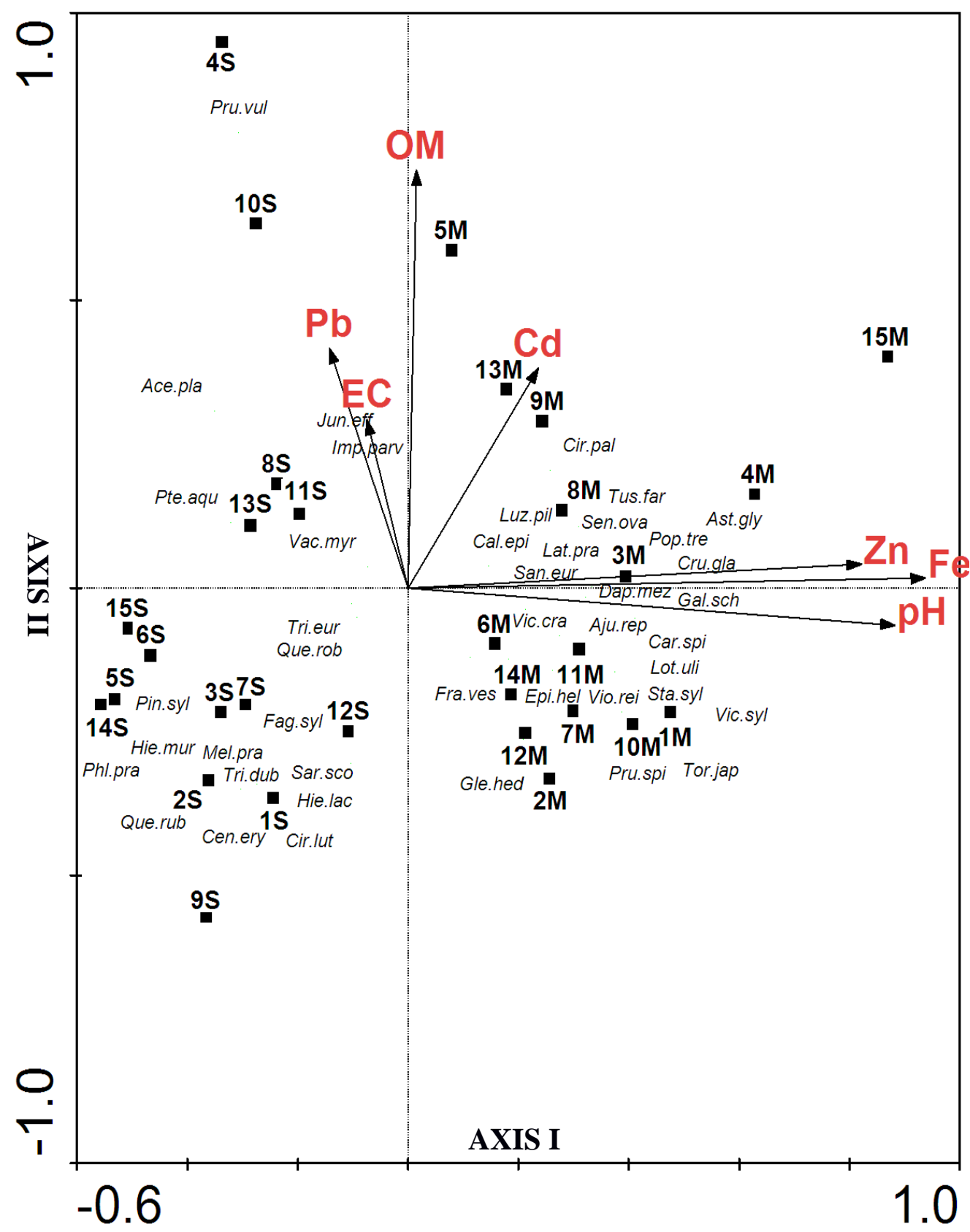

Figure 10. The relationship between soil properties and the species composition based on the results of CCA analysis ( $M-$ mounds, $S$ - surrounding area) 


\title{
Cluster Dendrogram
}

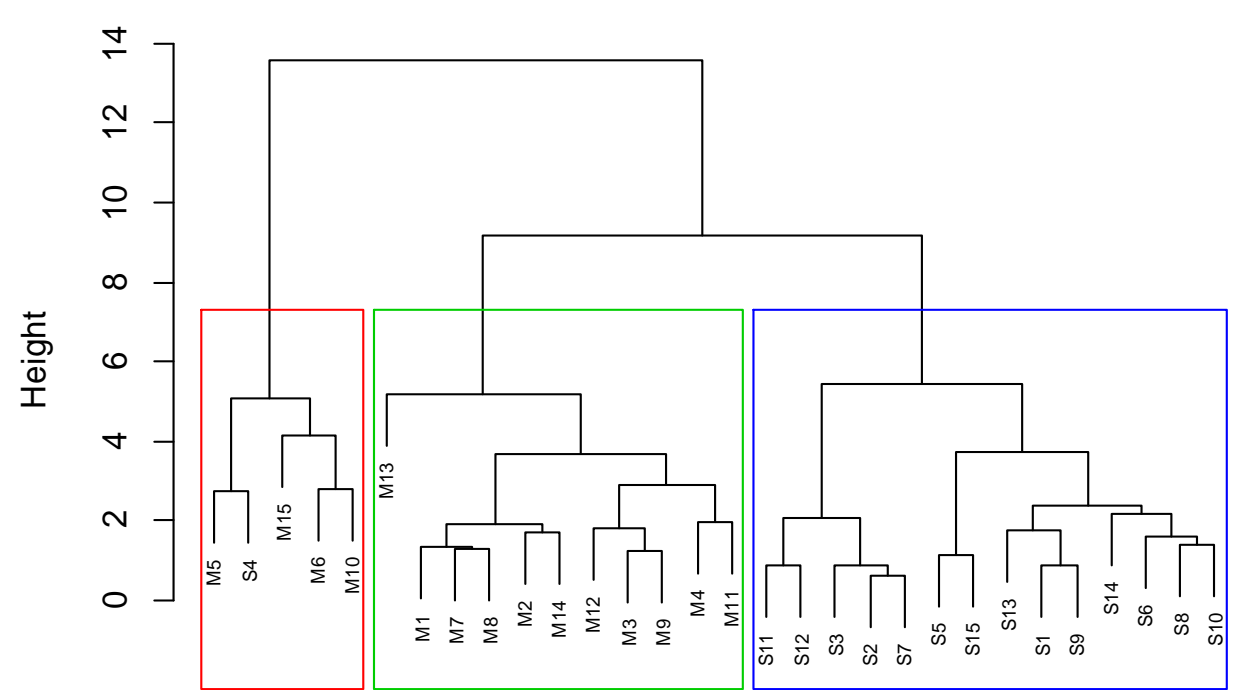

\author{
Plots \\ hclust (*, "ward.D2")
}

Figure 11. Cluster analysis (Ward method with Euclidean distance) of the physico-chemical soil properties measured on mound $(M)$ and surrounding area $(S)$ plots

\section{Discussion}

Based on the obtained results of analyses, which included all of previously listed biotic and abiotic variables, the mid-forest mounds are clearly distinguished, from the areas which surrounds them. Further studies showed, that, the floristic composition of plots consisted mainly of native species (apophytes), with a marginal contribution of alien species (kenophytes). Forest communities (from classes: Querco-Fagetea and Vaccinio-Piceetea) dominated in the composition of the flora in both types of plots studied (mounds and surrounding area), with a slightly higher contribution of species from Querco-Fagetea class on the mounds (35\%), than in the surrounding area (22\%). The higher values of contribution of species from Artemisietea-vulgaris class was noted on the mounds studied. The results of research conducted on the similar structures in the Gielniowski Hump (Małopolska Upland) also confirmed that, mesophilous forest communities, which consist of predominantly native species, can colonize these habitats more frequently. The studies also suggest that, throughout the extensive mining activities, the influence in local habitats could potentially increase the overall species richness (particularly by species from Querco-Fagetea class), as well as local diversity (Podgórska, 2010, 2016). During the studies we determined, that, some of the plant species were more commonly distributed on mounds, with their relatively high level of contribution, like Lathyrus pratensis or partially protected in Poland species Daphne mezereum. Other species like Acer platanoides or Hieracium murorum had relatively higher constancy in the surrounding area plots. Based on analyses of species distribution in each group of life strategies, the investigated plots were characterized by a high contribution of species representing the $\mathrm{C}$ (competitors) and CSR (competitors/stress 
tolerators/ruderals) strategies. It has been shown that, moderate disturbance and stress are factors which can potentially limit the process of competition between plant species on various anthropological habitats. Substantial contribution of plant species with $\mathrm{C}$ (competitors) strategy is also expected in places, where both human and natural stress factors (related to mining activities, fires or floods) have ceased to exist for a long time (Nowak, 2009). Sörensen's index of similarity showed that, the majority of mounds have a vast amount of common species, which can also occur in the surrounding area. Although, one of the biggest mound (number 9) had the lowest similarity index which contribute to the assumption that, large habitat islands have their own unique species pool. The results of diversity-area studies, based on the linear regression method, showed positive correlation between species diversity and size of inhabited mound (island), indicating strong relationship between those variables. Species richness is mostly related to the amount of different habitats created on the island. Typically, more spacious islands contain more types of habitats, which directly translates into increase in species richness (Kohn and Walsh, 1994; Rickless and Lovette, 1999). Also, due to the fact that, small islands consist of rather small species pools, different environmental modifications and human related disturbances, even at a relatively low level, can have a strong impact on the composition of the vascular plant flora which occupies them (Panitsa et al., 2006). However, in some individual cases, we can observe the "small island effect", where species diversity is actually independent from the size parameter (Triantis et al., 2006). According to the results of the canonical correlation analysis, the soil variables measured: $\mathrm{pH}$, content of $\mathrm{Fe}$ and $\mathrm{Zn}$, were considered as valid, key factors which explain the differences between observed groups (mounds and surrounding areas). Further division between plots have been shown to be influenced by other parameters, including organic matter (OM), electric conductivity (EC) and content of the heavy metals $\mathrm{Cd}$ and $\mathrm{Pb}$. High content of heavy metals, alongside other detrimental soil characteristics have been considered as one of the possible factors influencing the rate of colonization process by plant species on iron ore tailings Ma On Shan in the Hong Kong area (Wong and Tam, 1977). A variety of iron tailings and remnants are also characterized by significantly high amount of other heavy metals (including $\mathrm{Pb}, \mathrm{Zn}, \mathrm{Ni}$ and $\mathrm{Cu}$ ) (Zhang et al., 2006). Some studies also prove that, low $\mathrm{pH}$ values can have a strong impact on the composition of plants, representing typical woody communities (Podgórska, 2015; Peet et al., 2003). Some authors also claim that, values of $\mathrm{pH}$ between 5-6 are preferable for many plant species, although, when soil become more acidic or alkaline, the number of tolerant species decreases and more specialists start to occur (Schuster and Diekmann, 2003). In contrast, others suggest that, higher concentration of calcium $(\mathrm{Ca})$, which is often correlated with increased values of $\mathrm{pH}$, can possibly have more impact in the process of reclamation on a variety of mine tailings, than the higher uptake of heavy metals (Hossner and Hons, 1992).

\section{Conclusions}

The remnants of iron ore excavations undoubtedly play a significant role influencing the state of local diversity which was confirmed by increasing number of species (with native origin), representing typical woody communities. In result of long inactivity of mining process we observed strong contribution of species with $\mathrm{C}$ (competitors) life strategies, although species with CSR (competitors/stress tolerators/ruderals) were also significantly present in the composition of the vascular plant flora. During our studies 
we presented strong correlation between modified soil properties and species composition on the mounds investigated. The excavating process, which involves mining lower layers of soil and depositing the material on the surface resulted in completely altered soil parameters on the mounds, which promoted some of plant species to inhabit them, which led to some relevant differences in species composition, compared with the surrounding areas. The composition of vascular plant flora of former excavating sites indicates the process of their gradual naturalization, which manifests through the domination of native species and occurrence of some valuable species. Apart from the natural values of mounds studied, they can be also treated as a part of historical and cultural heritage.

Despite the negative affection of human disturbances on the mounds studied in this project, their appearance significantly improved the level of species richness and local biodiversity of typical forest habitats around Boronów district.

\section{REFERENCES}

[1] Andrén, H. (1997): Habitat fragmentation and changes in biodiversity. - Ecological Bulletins: 171-181.

[2] Braun-Banquet, J. (1928): Pflanzensoziologie. Grundzüge der Vegetationskunde. Biologische Studienbücher (7).

[3] Bzdon, G. (2008): Gravel pits as habitat islands: floristic diversity and vegetation analysis. - Pol. J. Ecol. 56(2): 239-250.

[4] Czylok, A., Szymczyk, A. (2009): Sand quarries as biotopes of rare and critically endangered plant species In: Rare, relict and endangered plants and fungi in Poland. - W. Szafer Institute of Botany, Polish Academy of Sciences: 187-192.

[5] Grime, J. P. (1979): Plant strategies and vegetation processes. - Willey \& Sons, Chichester-New York-Brisbane-Toronto.

[6] Grime, J. P. (2002): Plant strategies, vegetation processes and ecosystem properties. 2nd edition. - Willey \& Sons, Chichester.

[7] Hossner, L. R., Hons, F. M. (1992): Reclamation of mine tailings. In Soil Restoration. Springer, New York: 311-350.

[8] Klotz, F., Kühn, I., Durka, W. (2002): BIOLFLOR - Eine Datenbank mit biologischökologischen Merkmalen zur Flora von Deutschland. - Bundesamt für Naturschutz, Bonn - Bad Godesberg.

[9] Kohn, D. D., Walsh, D. M. (1994): Plant species richness-the effect of island size and habitat diversity. - Journal of Ecology: 367-377.

[10] Kruczała, A. M. (ed.) (2000): Atlas klimatu województwa śląskiego. - Instytut Meteorologii i Gospodarki Wodnej. Oddział Katowice.

[11] Lepš, J., Šmilauer, P. (2003): Multivariate analysis of ecological data using CANOCO. Cambridge University Press.

[12] Matuszkiewicz, W. (2007): A guide for identification of the plant communities of Poland. - Polish Scientific Publishers, PWN.

[13] Mirek, Z., Piekos-Mirkowa, H., Zajac, A., Zajac, M. (2002): Flowering plants and pteridophytes of Poland. A checklist. - Szafer Institute of Botany, PAN.

[14] Nowak, A. (2009): Diversity of vascular plants flora in anthropogenic habitats in Silesia. - In: Holeksa J., Babczyńska-Sendek B., Wika S. (ed.) The Role of Geobotany in Biodiversity conservation: 219-226.

[15] Operat siedliskowy dla Nadleśnictwa Koszęcin (2003): Biuro Urządzania Lasu I Geodezji Leśnej Oddział Kraków (in polish). 
[16] Panitsa, M., Tzanoudakis, D., Triantis, K. A., Sfenthourakis, S. (2006): Patterns of species richness on very small islands: the plants of the Aegean archipelago. - Journal of Biogeography 33(7): 1223-1234.

[17] Peet, R. K., Fridley, J. D., Gramling, J. M. (2003): Variation in species richness and species pool size across a $\mathrm{pH}$ gradient in forests of the southern Blue Ridge Mountains. Folia Geobotanica 38(4): 391-401.

[18] Podgórska, M. (2010): The impact of former iron ore mining on the transformation of vegetation cover of the Gielniowski Hump (Małopolska Upland). - Biodiv. Res. Conserv. (17): 53-62.

[19] Podgórska, M. (2015): Specific remnants of old iron-ore extraction sites as islands of plant species richness. - Open Life Sciences 10(1).

[20] Podgórska, M. (2016): The changes of species composition of forest phytocoenoses developed on former iron-ore mining areas after 40 years of secondary succession. Fragmenta Floristica et Geobotanica Polonica 23(1): 121-137.

[21] Řehounková, K., Prach, K. (2006): Spontaneous vegetation succession in disused gravelsand pits: Role of local site and landscape factors. - Journal of Vegetation Science 17(5): 583-590.

[22] Ricklefs, R. E., Lovette, I. J. (1999): The roles of island area per se and habitat diversity in the species-area relationships of four Lesser Antillean faunal groups. - Journal of Animal Ecology 68(6): 1142-1160.

[23] Rostański, A. (2005): Specific features of the flora of colliery spoil heaps in selected European regions. - Polish Botanical Studies (19): 97-103.

[24] Rostański, A. (2006): Spontaneous plant cover on colliery spoil heaps in Upper Silesia (Southern Poland) - Wydawnictwo Uniwersytetu Śląskiego, Katowice (in Polish with English summary).

[25] RStudio Team (2015). RStudio: Integrated Development for R. RStudio, Inc., Boston, MA

[26] Schuster, B., Diekmann, M. (2003): Changes in species density Changes in species density along the soil $\mathrm{pH}$ gradient - evidence from German plant communities. - Folia Geobotanica 38(4): 367-379.

[27] Statsoft Inc. (2011): STATISTICA (data analyses software system). Version 10. Available at www.statsoft.com.

[28] Ter Braak, C. J., Šmilauer, P. (2002): Reference manual and CanoDraw for Windows user's guide: software for canonical community ordination (version 4.5).

[29] Tokarska-Guzik, B. (2005): The establishment and spread of alien plant species (kenophytes) in the flora of Poland. - Wydawnictwo Uniwersytetu Śląskiego, Katowice

[30] Triantis, K. A., Vardinoyannis, K., Tsolaki, E. P., Botsaris, I., Lika, K., Mylonas, M. (2006): Re-approaching the small island effect. - Journal of Biogeography 33(5): 914-923.

[31] Whittaker, R. H. (1972): Evolution and measurement of species diversity. - Taxon: 213-251.

[32] Wilson, E. O., MacArthur, R. H. (1967): The theory of island biogeography. - Princeton, NJ.

[33] Wong, M. H., Tam, F. Y. (1977): Soil and vegetation contamination by iron-ore tailings. - Environmental Pollution (1970) 14(4): 241-251.

[34] Woś, A. (1999): Klimat Polski. - Wydawn. Naukowe PWN.

[35] Zhang, S., Xue, X., Liu, X., Duan, P., Yang, H., Jiang, T., Liu, R. (2006): Current situation and comprehensive utilization of iron ore tailing resources. - Journal of Mining Science 42(4): 403-408. 


\section{APPENDIX}

Appendix 1. List of plant species with their cover(Braun-Blanquet scale), which were noted on the plots (M-mounds, $S$ - surrounding area)

\begin{tabular}{|c|c|c|c|c|c|c|c|c|c|c|c|c|c|c|c|c|c|c|c|c|c|c|c|c|c|c|c|c|c}
\hline $\mathrm{M}$ & $\mathrm{M}$ & $\mathrm{M}$ & $\mathrm{M}$ & $\mathrm{M}$ & $\mathrm{M}$ & $\mathrm{M}$ & $\mathrm{M}$ & $\mathrm{M}$ & $\mathrm{M}$ & $\mathrm{M}$ & $\mathrm{M}$ & $\mathrm{M}$ & $\mathrm{M}$ & $\mathrm{M}$ & $\mathrm{S}$ & $\mathrm{S}$ & $\mathrm{S}$ & $\mathrm{S}$ & $\mathrm{S}$ & $\mathrm{S}$ & $\mathrm{S}$ & $\mathrm{S}$ & $\mathrm{S}$ & $\mathrm{S}$ & $\mathrm{S}$ & $\mathrm{S}$ & $\mathrm{S}$ & $\mathrm{S}$ & $\mathrm{S}$ \\
1 & 2 & 3 & 4 & 5 & 6 & 7 & 8 & 9 & 10 & 11 & 12 & 13 & 14 & 15 & 1 & 2 & 3 & 4 & 5 & 6 & 7 & 8 & 9 & 10 & 11 & 12 & 13 & 14 & 15 \\
\hline
\end{tabular}

\section{ChCl: Agropyretea}

\begin{tabular}{|c|c|c|c|c|c|c|c|c|c|c|c|c|c|c|c|c|c|c|c|c|c|c|c|c|c|c|c|c|c|c|c|}
\hline Equisetum arvense & $\mathrm{c}$ & . & . & . & . & . & . & . & . & . & . & . & . & 1 & . & 1 & . & . & . & . & . & . & . & . & . & . & . & . & 1 & . & . \\
\hline \multicolumn{32}{|c|}{ ChCl: Artemisietea vulgaris } \\
\hline Epilobium hirsutum & $\mathrm{c}$ & . & . & . & . & . & . & . & . & . & . & . & . & . & . & . & . & . & . & . & . & . & 1 & . & . & . & . & 1 & . & . & . \\
\hline Glechoma hederacea & $\mathrm{c}$ & 1 & 1 & . & . & . & . & . & . & . & . & . & 1 & . & . & . & . & . & . & . & . & . & . & . & . & . & . & 1 & . & . & . \\
\hline Impatiens parviflora & $\mathrm{c}$ & 1 & 2 & . & 1 & . & . & 2 & . & . & . & . & . & . & . & . & 2 & 1 & . & 3 & . & . & 1 & 1 & . & . & . & 1 & . & . & . \\
\hline Torilis japonica & $\mathrm{c}$ & 1 & . & . & . & . & . & 1 & . & . & . & . & . & . & . & . & . & . & . & . & . & . & . & . & . & . & . & . & . & . & . \\
\hline Urtica dioica & $\mathrm{c}$ & 2 & . & 1 & 2 & . & . & 2 & . & 1 & 2 & . & 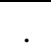 & 1 & . & . & 1 & 2 & & 2 & . & . & 1 & 2 & . & 2 & 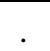 & . & 1 & . & 1 \\
\hline
\end{tabular}

Occasional species: Epilobium roseum(+), Galium aparine(r)

\section{ChCl: Epilobietea angustifolii}

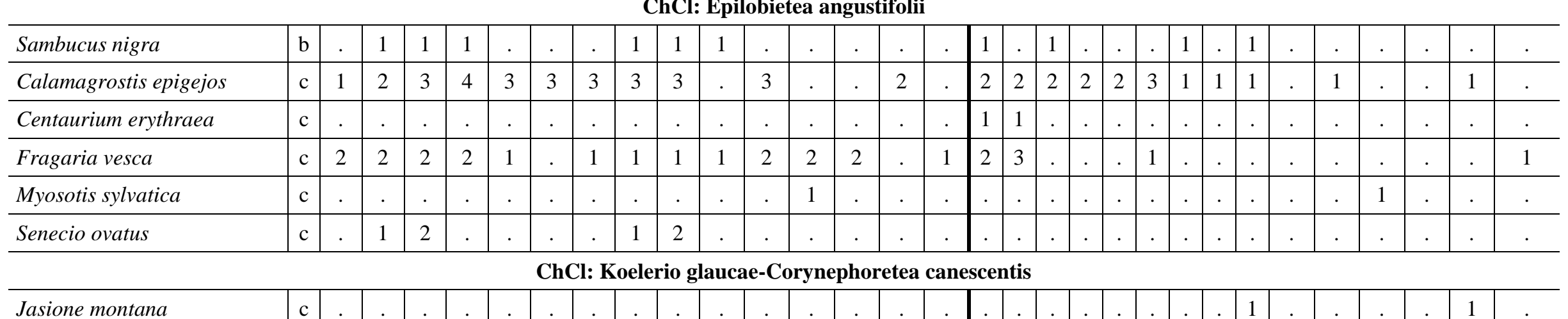

\section{ChCl: Molinio Arrhenatheretea}

Campanula patula

\begin{tabular}{|l|l|l|l|l|l|l|l|l|l|l|l|l|}
$\mathrm{c}$ & $\cdot$ & $\cdot$ & $\cdot$ & $\cdot$ & $\cdot$ & $\cdot$ & $\cdot$ & $\cdot$ & $\cdot$ & $\cdot$ & $\cdot$ & 1 \\
\hline $\mathrm{c}$ & $\cdot$ & $\cdot$ & 2 & $\mathrm{r}$ & 1 & $\cdot$ & $\cdot$ & $\cdot$ & $\cdot$ & $\cdot$ & 1 & \\
\hline
\end{tabular}

Cirsium palustre

APPLIED ECOLOGY AND ENVIRONMENTAL RESEARCH 15(4):1541-1563.

http://www.aloki.hu • ISSN 15891623 (Print) • ISSN 17850037 (Online)

DOI: http://dx.doi.org/10.15666/aeer/1504_15411563

(c) 2017, ALÖKI Kft., Budapest, Hungary 


\begin{tabular}{|c|c|c|c|c|c|c|c|c|c|c|c|c|c|c|c|c|c|c|c|c|c|c|c|c|c|c|c|c|c|c|c|}
\hline Deschampsia caespitosa & $\mathrm{c}$ & 1 & 1 & . & 1 & 1 & 2 & . & 1 & . & . & 1 & . & . & . & . & 1 & . & . & 1 & 1 & 2 & 1 & . & . & . & 1 & . & . & . & . \\
\hline Juncus effusus & $\mathrm{c}$ & 1 & . & 1 & . & . & . & 1 & 1 & . & & . & $\cdot$ & . & . & . & 1 & . & . & 2 & . & . & 1 & 1 & . & . & . & 1 & 1 & . & $\cdot$ \\
\hline Lathryus pratensis & $\mathrm{c}$ & . & 1 & . & 1 & 1 & . & 1 & . & 1 & & 1 & 1 & . & . & . & . & . & . & . & . & . & . & . & . & . & . & . & . & . & . \\
\hline Lotus uliginosus & $\mathrm{c}$ & 1 & . & 1 & 1 & . & . & 1 & 1 & 1 & & 1 & 1 & . & . & . & . & . & . & . & . & . & . & . & 1 & . & . & . & . & . & . \\
\hline Lychnis flos-cuculi & $\mathrm{c}$ & . & . & . & . & . & . & + & . & 2 & & . & ${ }^{\circ}$ & . & . & . & . & . & . & . & . & . & . & . & . & . & . & . & . & . & • \\
\hline Lysimachia vulgaris & $\mathrm{c}$ & . & . & . & . & . & . & 1 & . & . & $\cdot$ & . & . & . & . & . & . & . & 2 & . & 1 & . & . & . & . & . & . & . & . & . & . \\
\hline Potentilla anserina & $\mathrm{c}$ & . & . & . & . & . & . & . & . & . & $\cdot$ & . & . & . & . & . & . & . & . & . & . & . & . & 1 & . & . & . & 1 & . & . & . \\
\hline Prunella vulgrais & $\mathrm{c}$ & . & . & . & . & . & . & . & . & . & . & . & . & . & . & . & . & . & . & 1 & . & . & . & . & . & 1 & . & . & . & . & . \\
\hline Ranunculus repens & $\mathrm{c}$ & 1 & . & . & . & . & . & 1 & . & . & . & . & . & 1 & . & . & . & . & . & . & . & . & . & . & . & . & . & . & . & . & . \\
\hline Selinum carvifolia & $\mathrm{c}$ & 1 & 1 & . & . & . & . & 1 & 1 & . & . & . & . & . & . & . & . & . & . & . & . & . & . & . & . & . & . & . & . & . & 1 \\
\hline Trifolium dubium & $\mathrm{c}$ & . & . & . & . & . & . & . & . & . & . & . & . & . & . & . & 1 & . & . & . & . & . & 1 & . & . & . & . & . & . & . & . \\
\hline Vicia cracca & $\mathrm{c}$ & 1 & 1 & . & 1 & 1 & . & 1 & 1 & . & 1 & 1 & . & . & . & . & . & 1 & . & . & . & . & . & 1 & . & . & . & . & . & . & . \\
\hline \multicolumn{32}{|c|}{ Occasional species: Phleum pratense $(+)$} \\
\hline \multicolumn{32}{|c|}{ ChCl: Nardo-Callunetea } \\
\hline Agrostis capillaris & $\mathrm{c}$ & . & . & . & . & . & . & . & . & . & . & . & . & . & . & . & . & . & . & . & . & . & 1 & 1 & . & . & . & . & . & . & . \\
\hline Calluna vulgaris & $\mathrm{c}$ & . & . & . & . & . & . & . & . & . & . & . & . & . & . & . & 1 & . & . & . & . & 2 & . & . & . & . & . & . & . & . & . \\
\hline Hieracium lachenalii & $\mathrm{c}$ & . & . & . & . & . & . & 1 & . & . & $\cdot$ & . & . & . & . & . & 1 & 1 & . & . & . & . & . & . & . & . & . & . & . & . & . \\
\hline Luzula multiflora & $\mathrm{c}$ & . & . & . & 1 & . & . & 1 & 2 & . & $\cdot$ & 1 & . & . & . & . & . & . & . & . & . & . & . & . & . & . & . & . & . & . & . \\
\hline Potentilla erecta & $\mathrm{c}$ & . & . & . & 1 & . & . & . & . & . & 1 & . & . & . & . & 1 & 1 & 1 & 1 & 1 & 1 & . & 1 & 1 & 1 & 1 & 1 & . & . & . & 1 \\
\hline Veronica officinalis & $\mathrm{c}$ & 1 & . & 1 & . & . & . & 1 & . & 1 & ${ }^{\circ}$ & . & . & 1 & 1 & 1 & 1 & . & 1 & . & . & 1 & 1 & . & 1 & . & . & 1 & . & . & 1 \\
\hline \multicolumn{32}{|c|}{ ChCl: Phragmitetea } \\
\hline Scutellaria galericulata & $\mathrm{c}$ & . & . & . & . & . & . & . & . & . & & . & ${ }^{\circ}$ & 1 & . & . & & . & . & . & . & . & . & . & . & . & . & $\cdot$ & . & . & . \\
\hline \multicolumn{32}{|c|}{ ChCl: Quercetea robori-petraeae } \\
\hline Hieracium murorum & $\mathrm{c}$ & . & . & . & . & . & . & . & $\cdot$ & . & & $\cdot$ & . & . & $\cdot$ & & 2 & . & 2 & . & 1 & 1 & 1 & . & 1 & . & . & . & . & . & . \\
\hline \multicolumn{32}{|c|}{ ChCl: Querco-Fagetea } \\
\hline Acer platanoides & a & . & . & . & . & . & . & . & . & . & . & . & . & . & . & . & & 1 & . & 1 & . & . & . & . & . & . & . & . & . & . & \\
\hline
\end{tabular}




\begin{tabular}{|c|c|c|c|c|c|c|c|c|c|c|c|c|c|c|c|c|c|c|c|c|c|c|c|c|c|c|c|c|c|c|c|}
\hline Fagus sylvatica & $\mathrm{a}$ & . & 1 & . & . & & . & . & . & . & $\cdot$ & 1 & . & . & . & . & 1 & 1 & 1 & . & 1 & 1 & . & & . & . & $\cdot$ & . & . & . & $\cdot$ \\
\hline Corylus avellana & $\mathrm{b}$ & 1 & . & . & . & 1 & . & . & . & . & . & . & . & . & . & . & 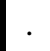 & . & . & . & . & . & . & . & . & . & . & . & . & . & $\cdot$ \\
\hline Daphne mezereum & $\mathrm{b}$ & 1 & 1 & 1 & 1 & 1 & . & 1 & . & . & 1 & 1 & . & 1 & 1 & . & 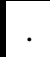 & . & . & . & . & . & . & . & . & . & . & . & . & . & . \\
\hline Actaea spicata & $\mathrm{c}$ & . & 1 & . & 1 & . & . & . & . & . & . & . & . & 1 & . & . & 1 & . & . & . & . & . & . & . & . & . & . & . & . & . & . \\
\hline Aegopodium podagraria & $\mathrm{c}$ & 1 & . & . & . & . & . & . & . & . & 1 & . & . & . & . & . & $\cdot$ & . & . & . & . & . & . & . & . & 2 & . & . & . & . & $\cdot$ \\
\hline Carex remota & $\mathrm{c}$ & . & . & . & . & . & . & . & . & . & . & . & 2 & . & . & . & . & . & . & . & . & . & . & . & 1 & . & . & . & . & . & • \\
\hline Carex sylvatica & $\mathrm{c}$ & . & . & . & 1 & . & . & . & . & . & . & . & . & . & . & . & . & 1 & . & 1 & . & . & 1 & 1 & . & . & . & . & 1 & . & . \\
\hline Circaea lutetiana & $\mathrm{c}$ & . & . & . & . & . & . & . & . & . & . & . & . & . & . & . & 3 & • & 2 & . & . & & . & . & 1 & . & . & . & . & . & - \\
\hline Dryopteris filix-mas & $\mathrm{c}$ & . & . & . & . & . & . & . & . & . & . & . & 1 & 1 & . & 1 & 1 & 1 & 1 & 1 & . & . & 1 & 1 & . & . & . & . & 1 & . & 1 \\
\hline Epipactis helleborine & $\mathrm{c}$ & 1 & . & 1 & 1 & . & . & . & . & . & . & . & . & . & . & . & 1 & . & 1 & . & . & . & . & . & . & . & . & . & . & . & . \\
\hline Festuca gigantea & $\mathrm{c}$ & . & . & . & . & . & . & . & . & . & . & . & . & . & . & . & . & . & . & . & . & . & . & . & . & . & . & 1 & . & . & . \\
\hline Galium schultesii & $\mathrm{c}$ & . & . & . & 1 & . & . & 1 & 1 & . & . & 1 & . & . & . & . & . & . & . & . & . & . & . & . & . & . & . & . & . & . & . \\
\hline Melica nutans & $\mathrm{c}$ & . & . & . & . & . & . & . & . & . & . & 1 & 2 & . & . & . & . & . & . & . & . & . & . & . & . & . & . & . & . & . & . \\
\hline Sanicula europaea & $\mathrm{c}$ & 2 & 2 & 2 & 2 & . & . & 2 & 2 & 2 & 2 & . & . & 2 & . & 1 & & 1 & . & . & . & . & . & 1 & . & . & . & . & . & . & . \\
\hline Stachys sylvatica & $\mathrm{c}$ & 2 & . & 1 & . & . & . & 2 & . & 1 & . & . & . & . & . & . & . & . & . & . & . & . & . & . & . & . & . & . & . & . & . \\
\hline Viola reichenbachiana & $\mathrm{c}$ & 2 & 2 & 1 & 1 & . & . & 2 & 2 & 1 & 1 & . & . & . & 3 & . & 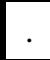 & . & . & . & . & . & . & . & . & . & . & . & . & 1 & \\
\hline
\end{tabular}

Occasional species: Scrophularia nodosa(1)

\begin{tabular}{|c|c|c|c|c|c|c|c|c|c|c|c|c|c|c|c|c|c|c|c|c|c|c|c|c|c|c|c|c|c|c|}
\hline \multicolumn{31}{|c|}{ ChCl: Rhamno-Prunetea } \\
\hline Prunus spinosa & $\mathrm{c}$ & 1 & . & . & . & . & . & 1 & . & . & . & . & . & . & . & . & . & . & . & . & . & . & . & . & . & . & . & . & . & \\
\hline Sarothamnus scoparius & $\mathrm{c}$ & . & . & . & . & . & . & . & . & . & . & . & . & . & . & 1 & . & . & . & . & . & $\mathrm{r}$ & . & . & . & . & . & . & . & . \\
\hline \multicolumn{31}{|c|}{ ChCl: Scheuchzerio-Caricetea nigrae } \\
\hline Stellaria palustris & $\mathrm{c}$ & . & . & . & 2 & . & . & . & . & . & 2 & . & . & . & . & & 1 & . & . & . & . & . & 1 & . & . & . & . & 1 & . & \\
\hline \multicolumn{31}{|c|}{ ChCl: Trifolio-Geranietea sanguinei } \\
\hline Astragalus glycyphyllos & $\mathrm{c}$ & . & $\cdot$ & . & 1 & $\cdot$ & . & . & . & . & . & . & . & $\mathrm{r}$ & . & . & . & . & $\cdot$ & . & . & . & $\cdot$ & $\cdot$ & . & . & . & $\cdot$ & . & . \\
\hline Vicia sylvativa & $\mathrm{c}$ & 2 & . & . & . & . & . & 2 & . & . & . & . & . & . & . & 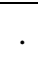 & . & . & . & . & . & . & . & . & . & . & . & . & . & \\
\hline
\end{tabular}




\begin{tabular}{|c|c|c|c|c|c|c|c|c|c|c|c|c|c|c|c|c|c|c|c|c|c|c|c|c|c|c|}
\hline \multicolumn{27}{|c|}{ ChCl:Vaccinio-Piceetea } \\
\hline Picea abies & a & . & . & . & 1 & 1 & . & 1 & 1 & 1 & . & & & . & . & 1 & . & 1 & 1 & 1 & & . & . & 1 & . & 1 \\
\hline Pinus sylvestris & a & . & . & . & . & . & 1 & . & . & . & $\cdot$ & & 1 & - & . & 2 & 2 & . & . & 1 & & . & . & . & . & - \\
\hline Dryopteris dilatata & $\mathrm{c}$ & . & . & . & . & . & . & . & . & . & ${ }^{\circ}$ & & 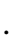 & . & 1 & . & . & 1 & . & . & & . & 1 & . & 2 & 1 \\
\hline Melampyrum pratense & $\mathrm{c}$ & . & 2 & . & . & . & . & . & . & . & . & $\cdot$ & 2 & . & . & 2 & 2 & . & . & . & & . & . & . & 2 & . \\
\hline Trientalis europaea & $\mathrm{c}$ & 2 & 1 & 1 & 1 & . & 1 & 2 & 1 & 1 & 1 & & 1 & 2 & 2 & 2 & . & 2 & 1 & 2 & & 2 & . & . & . & . \\
\hline Vaccinium myrtillus & $\mathrm{c}$ & 2 & 4 & 2 & . & 5 & 3 & 2 & 4 & 2 & $\cdot$ & 5 & 3 & 3 & 4 & 4 & 3 & 3 & 3 & 3 & & 4 & 3 & 1 & . & 1 \\
\hline \multicolumn{27}{|c|}{ Accompanying species } \\
\hline Betula pendula & $\mathrm{a}$ & . & . & . & 1 & 1 & 1 & 1 & 1 & 1 & . & & 1 & . & . & . & . & 1 & 1 & . & & . & . & . & . & . \\
\hline Larix decidua & $\mathrm{a}$ & . & . & . & . & . & 1 & . & . & . & . & & • & . & . & 1 & . & . & . & 1 & & . & . & . & . & . \\
\hline Populus tremula & $\mathrm{a}$ & . & . & . & 2 & . & 1 & . & . & . & . & $\cdot$ & 1 & . & . & . & . & . & . & . & & . & . & . & . & • \\
\hline Quercus robur & $\mathrm{a}$ & 1 & 1 & . & 1 & 1 & 1 & 1 & 1 & . & 1 & 1 & 2 & 1 & 1 & 1 & 1 & 1 & 2 & 1 & & 1 & 1 & . & . & . \\
\hline Frangula alnus & $\mathrm{b}$ & . & . & 1 & . & . & . & . & 1 & . & . & $\cdot$ & 2 & . & 1 & . & . & . & 1 & . & & . & . & . & . & . \\
\hline Sorbus aucuparia & $\mathrm{b}$ & . & 1 & . & . & . & 1 & . & 1 & . & . & 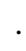 & 1 & . & . & . & . & . & 1 & . & & . & . & . & . & . \\
\hline Ajuga reptans & $\mathrm{c}$ & 1 & 1 & 1 & 1 & . & . & 1 & . & . & . & $\cdot$ & 1 & . & . & . & . & . & . & . & & . & . & . & . & . \\
\hline Carex spicata & $\mathrm{c}$ & . & . & . & 1 & . & . & 1 & . & . & . & 1 & $\cdot$ & . & . & . & . & . & . & . & & . & . & . & . & . \\
\hline Deschampsia flexuоsa & $\mathrm{c}$ & . & 2 & . & 2 & 2 & 3 & . & 2 & 3 & . & 2 & 1 & . & 2 & 2 & 2 & 2 & 4 & . & & 2 & 1 & . & 1 & . \\
\hline Equisetum sylvaticum & $\mathrm{c}$ & . & . & . & . & . & . & 1 & . & 1 & . & 1 & . & . & . & . & . & . & . & . & & 1 & 1 & 2 & . & 2 \\
\hline Hypericum perforatum & $\mathrm{c}$ & . & . & . & 1 & . & . & 1 & 1 & . & . & $\cdot$ & . & . & 1 & . & . & 1 & 1 & . & & . & 1 & 1 & . & 1 \\
\hline Luzula pilosa & $\mathrm{c}$ & 2 & 1 & 2 & 2 & 1 & . & 1 & 1 & . & . & ${ }^{\circ}$ & 1 & 2 & 2 & . & . & . & . & . & & . & . & . & 1 & . \\
\hline Maianthemum bifolium & $\mathrm{c}$ & 3 & 1 & 2 & . & 1 & . & . & . & . & . & 1 & 1 & 1 & . & 2 & . & . & . & . & & 2 & . & . & . & . \\
\hline Mycelis muralis & $\mathrm{c}$ & 3 & 1 & 1 & . & . & . & 2 & 1 & 1 & . & . & 2 & 2 & 2 & 1 & . & 2 & . & . & & . & 1 & . & . & . \\
\hline Oxalis acetosella & $\mathrm{c}$ & 3 & 2 & . & 2 & . & . & 1 & 1 & . & 1 & 2 & 2 & . & 2 & . & . & 1 & . & . & & 2 & . & 1 & . & 2 \\
\hline Polygonum persicaria & $\mathrm{c}$ & . & . & . & . & . & . & . & . & . & . & 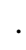 & . & . & . & . & . & 1 & 1 & . & & . & 1 & . & . & . \\
\hline Pteridium aquilinum & $\mathrm{c}$ & . & . & . & $\cdot$ & . & . & . & . & . & . & ${ }^{\circ}$ & 4 & . & 4 & 4 & . & 3 & 4 & . & & 4 & . & . & 3 & . \\
\hline Rubus saxatilis & $\mathrm{c}$ & 2 & . & 1 & . & 1 & 1 & 2 & . & 1 & . & 1 & & . & 1 & . & . & 3 & . & . & & . & . & . & . & . \\
\hline
\end{tabular}

APPLIED ECOLOGY AND ENVIRONMENTAL RESEARCH 15(4):1541-1563.

http://www.aloki.hu • ISSN 15891623 (Print) • ISSN 17850037 (Online)

DOI: http://dx.doi.org/10.15666/aeer/1504_15411563

(๖ 2017, ALÖKI Kft., Budapest, Hungary 


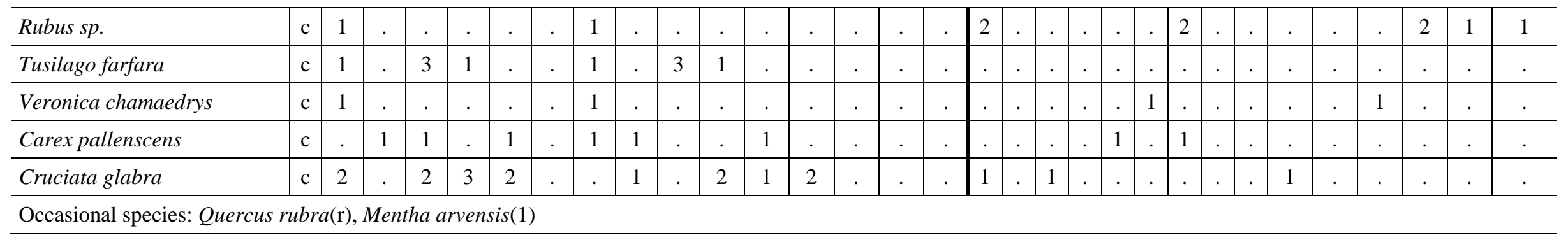

Appendix 2. Detailed characteristics of collected soil samples (M-mounds, $S$ - surrounding area)

\begin{tabular}{|c|c|c|c|c|c|c|c|c|}
\hline Plot & $\begin{array}{c}\text { pH } \\
\left(\mathbf{H}_{2} \mathbf{O}\right)\end{array}$ & $\begin{array}{c}\mathrm{EC} \\
(\mu \mathrm{S})\end{array}$ & $\begin{array}{l}\text { OM } \\
(\%) \\
\end{array}$ & $\begin{array}{c}\mathrm{CaCO}_{3} \\
(\%)\end{array}$ & $\begin{array}{c}\mathrm{Cd} \\
\left(\mathrm{mg} \mathrm{kg}^{-1}\right)\end{array}$ & $\begin{array}{c}\mathrm{Pb} \\
\left(\mathrm{mg} \mathrm{kg}^{-1}\right)\end{array}$ & $\begin{array}{c}\mathrm{Zn} \\
\left(\mathrm{mg} \mathrm{kg}^{-1}\right)\end{array}$ & $\begin{array}{c}\text { Fe } \\
\left(\mathrm{mg} \mathrm{kg}^{-1}\right) \\
\end{array}$ \\
\hline M1 & 5.21 & 73 & 13.07 & 0 & 1.15 & 56.65 & 184.08 & 59986.93 \\
\hline M2 & 4.59 & 79 & 13.11 & 0 & 0.77 & 85.42 & 157.86 & 69695.84 \\
\hline M3 & 5.08 & 72 & 13.10 & 0.215 & 1.03 & 48.95 & 149.80 & 54857.24 \\
\hline M4 & 5.57 & 60 & 11.45 & 0.084 & 0.43 & 28.54 & 136.33 & 76652.67 \\
\hline M5 & 4.63 & 162 & 26.13 & 0.00 & 2.52 & 116.47 & 152.34 & 35783.39 \\
\hline M6 & 4.9 & 181 & 28.51 & 0.123 & 4.08 & 187.13 & 265.38 & 44389.89 \\
\hline M7 & 5.12 & 59 & 11.17 & 0 & 0.41 & 39.71 & 125.79 & 46078.20 \\
\hline M8 & 4.75 & 60 & 14.16 & 0 & 1.31 & 44.76 & 148.92 & 35425.22 \\
\hline M9 & 4.6 & 67 & 16.47 & 0.213 & 1.33 & 76.83 & 136.82 & 54100.29 \\
\hline M10 & 5.82 & 207 & 25.76 & 0.294 & 2.97 & 128.25 & 250.57 & 46091.42 \\
\hline M11 & 5.46 & 96 & 14.00 & 0.211 & 0.19 & 25.77 & 114.34 & 35899.92 \\
\hline M12 & 4.67 & 96 & 12.16 & 0.343 & 0.90 & 36.88 & 151.24 & 33975.23 \\
\hline M13 & 4.37 & 102 & 18.68 & 0.583 & 0.47 & 32.76 & 124.41 & 31677.81 \\
\hline M14 & 4.42 & 103 & 13.65 & 0 & 0.39 & 37.54 & 141.12 & 41204.03 \\
\hline M15 & 4.93 & 174 & 18.49 & 0.164 & 2.62 & 82.56 & 268.98 & 115742.41 \\
\hline S1 & 4.42 & 76 & 11.13 & 0.083 & 0.47 & 63.21 & 61.76 & 11306.04 \\
\hline
\end{tabular}


Strzeleczek et al.: The remnants of mid-forest iron ore excavations as a refuge for local diversity in the vascluar plant flora $1563-$

\begin{tabular}{|c|c|c|c|c|c|c|c|c|}
\hline S2 & 4.15 & 44 & 3.98 & 0.042 & 0.22 & 28.24 & 10.34 & 399.58 \\
\hline S3 & 4.03 & 68 & 5.07 & 0 & 0.21 & 21.59 & 13.61 & 3135.83 \\
\hline S4 & 4.32 & 137 & 34.62 & 0.206 & 2.04 & 165.01 & 75.91 & 13272.69 \\
\hline S5 & 3.5 & 168 & 17.44 & 0 & 0.41 & 83.83 & 45.85 & 3653.62 \\
\hline S6 & 3.62 & 81 & 12.11 & 0 & 0.53 & 66.25 & 35.06 & 2050.26 \\
\hline S7 & 4.23 & 32 & 3.74 & 0 & 0.03 & 12.55 & 4.99 & 392.44 \\
\hline S8 & 3.91 & 86 & 18.46 & 0.119 & 0.80 & 75.03 & 80.65 & 11508.58 \\
\hline S9 & 4.53 & 82 & 11.45 & 0.161 & 0.58 & 89.48 & 52.01 & 9032.99 \\
\hline S10 & 3.86 & 70 & 17.77 & 0.128 & 0.21 & 38.51 & 20.46 & 2052.99 \\
\hline S11 & 4.55 & 69 & 10.34 & 0 & 0.35 & 27.47 & 19.72 & 4593.73 \\
\hline S12 & 4.64 & 67 & 7.86 & 0.042 & 0.51 & 38.90 & 56.29 & 17562.58 \\
\hline S13 & 4.21 & 69 & 15.62 & 0.295 & 0.45 & 67.52 & 42.11 & 8078.88 \\
\hline S14 & 3.77 & 103 & 12.95 & 0.169 & 1.48 & 106.89 & 45.88 & 6314.13 \\
\hline S15 & 3.68 & 140 & 13.31 & 0 & 0.44 & 59.55 & 21.11 & 1295.97 \\
\hline
\end{tabular}

